\title{
Характеристика структурних змін внутрішніх органів при гострому панкреатиті за умови поліморбідності
}

\begin{abstract}
Мета роботи: з’ясувати закономірності процесів ремоделювання внутрішніх органів померлих від ускладненого панкреатиту за умов поліморбідності.

Матеріали і методи. Проведено ретроспективний аналіз163 протоколів розтинів і патогістологічного дослідження некропсій померлих від гострої хірургічної патології. Серед них гострий панкреатит як основне захворювання діагностовано у 30 осіб, що становить 18,5 \% від усієї кількості проаналізованих протоколів.

Результати досліджень та їх обговорення. За даними розтину діагностовано супутню серцево-судинну патологію, а саме атеросклероз аорти ( 73,3 \%), IXC (60,0%), артеріальну гіпертензію (60,1%), а також ХОЗЛ (63,3 \%) і ендокринопатії (23,3 \%) В цілому індекс поліморбідності становив 4,7. Струтурною складовою поліорганної недостатності при гострому панкреатиті є комплекс структурних змін серця, нирок, легень, печінки і надниркових залоз. Мікроскопічним дослідженням встановлено, що постійною складовою в патогенезі поліорганної недостатності при гострому панкреатиті є наявність різного ступеня виразності розладів кровообігу у всіх внутрішніх органах.
\end{abstract}

Ключові слова: внутрішні органи; гострий панкреатит; поліморбідність.

Постановка проблеми і аналіз останніх досліджень та публікацій. На сьогодні клінічний перебіг більшості хвороб органів травлення, підшлункової залози зокрема, має дві особливості агресивність процесу та поліморбідність [3]. Вважається, що поліморбідність $є$ наслідком впливу широкої палітри етіологічних чинників, які спричиняють одночасно пошкодження кількох органів і систем. Проте морфологічний субстрат поліорганності при більшості хірургічних хвороб недостатньо розкрито, часто має суперечливий характер $[5,6]$. Зазначене положення стосується і гострого панкреатиту (ГП).

За останні 30 років частота ГП серед гострих захворювань живота збільшиась від 1 до 12 \%. ГП належить до найбільш частих хірургічних захворювань та щорічно уражає 20-80 осіб на 100 тис. населення на рік. На його частку припадає 5-10 \% ургентної патології органів черевної порожнини, ГП посідає третє (25 \%) місце після гострого холециститу (28 \%) і гострого апендициту (26 \%). У кожного четвертого хворого розвивається некротичний панкреатит. Летальність при ГП складає 13-15 \%, а при деструктивній інфікованій формі $-20-50 \%[1,7,9]$.

Тому питання з'ясування морфофункціонального стану органів і систем особливо важливе як для теоретичної, так і практичної медицини. Оскільки можуть бути підгрунтям вибору оптимальних схем комплексного лікування $[8,10]$.
Мета роботи: з'ясувати закономірності процесів ремоделювання внутрішніх органів померлих від ускладненого панкреатиту за умов поліморбідності.

Матеріали і методи. Проведено ретроспективний аналіз 163 протоколів розтинів і патогістологічних висновків дослідження некропсій померлих від гострої хірургічної патології. Серед них гострий панкреатит як основне захворювання діагностовано у 30 осіб, що склало 18,5 \% від усіх проаналізованих протоколів.

Враховуючи, що поліморбідність суттєво впливає на перебіг хвороби і танатогенез, проведено аналіз ії̈ складових. Найбільш часто за даними розтину діагностовано супутню серцево-судинну патологію, а саме атеросклероз аорти (73,3 \%), IXC (60,0 \%), артеріальну гіпертензію (60,1\%), а також ХОЗЛ (63,3 \%) і ендокринопатії (23,3 \%). У цілому індекс поліморбідності становив 4,7.

Результати досліджень та їх обговорення. Домінування у загальній структурі комплексу супутніх захворювань у хворих на ГП: міокардіодистрофії, респіраторного дистрес-синдрому дорослих, гострої ниркової, печінкової та надниркової недостатності зумовили безпосередню причину смерті зазначених пацієнтів, що пояснюється єдністю патогенетичних ланок ураження внутрішніх органів і трактується як поліорганна недостатність. 
Морфологічні зміни підшлункової залози при ГП поліморфні і характеризуються мозаїчністю навіть у невеликій ділянці залози спостерігаються гетерогенні прояви патологічного процесу - розлади кровообігу в поєднанні з альтеративними та проліферативними змінами із переважанням одного із компонентів залежно від типу панкреатиту.

Типовими гістологічними змінами для всіх типів ушкодження підшлункової залози були вогнищево-дифузне капілярно-венозне повнокров'я, набряк строми від слабко вираженого до сильного, дифузне та перидуктальне розволокнення строми з вогнищевим помірним продуктивним запаленням, середньо- та великовогнищевим ліпоматозом залози. Інсулярні острівці в стані екстацилюлярного набряку різного ступеня вираження. Острівці Лангерганса різко збільшені в розмірах за рахунок гіперплазії. В частині полів зору розміщені осередки некрозу тканини залози різного розміру з виразною перифокальною лейкоцитарною інфільтрацією.

У міокарді на перший план виступали розлади кровообігу, які проявлялись дифузним виразним венозним та капілярним повнокров'ям з еритростазами. Перивазальна та інтерстиціальна тканина була помірно пухкою за рахунок набряку. Стінки артеріол із збереженою світлооптично структурою. Просвіти окремих артеріол у стані дистонії, нерізкого спазму, ендотеліоцити набряклі, місцями десквамовані із осередками десквамації; адвентиція помірно пухка за рахунок набряку.

Зміни міокарда гетерогенні. Цитоплазма кардіоміоцитів забарвлена нерівномірно. В багатьох клітинах відсутня поперечна посмугованість, цитоплазма у зазначених ділянках фарбується від еозинофільної до базофільної. Серед кардіоміоцитів із слабкою і помірною гіпертрофією окремих клітин проявляються стоншені, у поєднанні із вираженим вогнищевим периваскулярним ліпоматозом та осередковою круглоклітинною інфільтрацією, строми.

Характерно, що при ГП наявні осередки вираженої фрагментації та хвилеподібної деформації кардіоміоцитів (рис. 1).

Зазначений феномен ми схильні розцінювати як морфологічні ознаки можливого порушення ритму серця, що підверджено дослідженнями міокарда при інтоксикаціях [4] та гіпоксичних станах [2].

Поряд із структурними проявами міокардіодистрофії та фрагментації скоротливих кардіоміоцитів у всіх спостереженнях виявлено морфологічні прояви гострої дихальної недостатності. Так, гістологічно встановлено розлади кровообігу, які

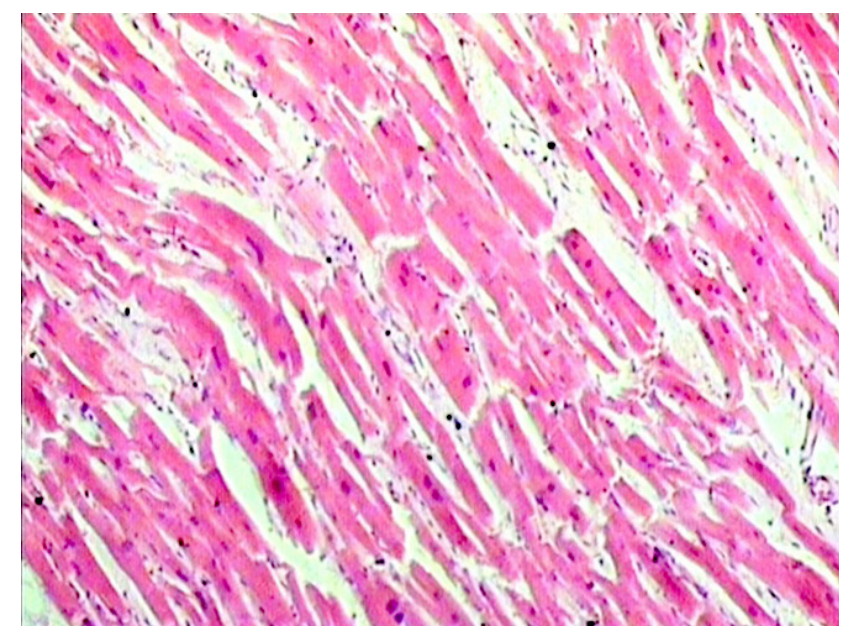

Рис. 1. Виражений набряк строми, фрагментація скоротливих кардіоміоцитів. Гістологічний зріз некропсії серця. Забарвлення гематоксиліном і еозином. ×100.

проявлялися дилатацією судин різного калібру та їхнім повнокров’ям. Основна маса крові концентрувалася в мікроциркуляторному руслі. В розширених венозних судинах дрібного та середнього калібру спостерігали набухання і десквамацію ендотеліоцитів, сладж еритроцитів, подекуди сепарацію крові та мікротромби. Альвеоли були різного розміру, їхні просвіти набували щілиноподібного вигляду, на багатьох дрібних ділянках візуалізувалися ателектази. Просвіти розміщених поряд альвеол емфізематозно розширені. Набряк міжчасточкового інтерстицію поєднувався із альвеолярним (рис. 2).

Світлооптичні зміни нирок при ГП проявлялись різним ступенем виразності розладів кровообігу, пошкодженнями клубочків і канальців, що можна трактувати як морфологічну основу роз-

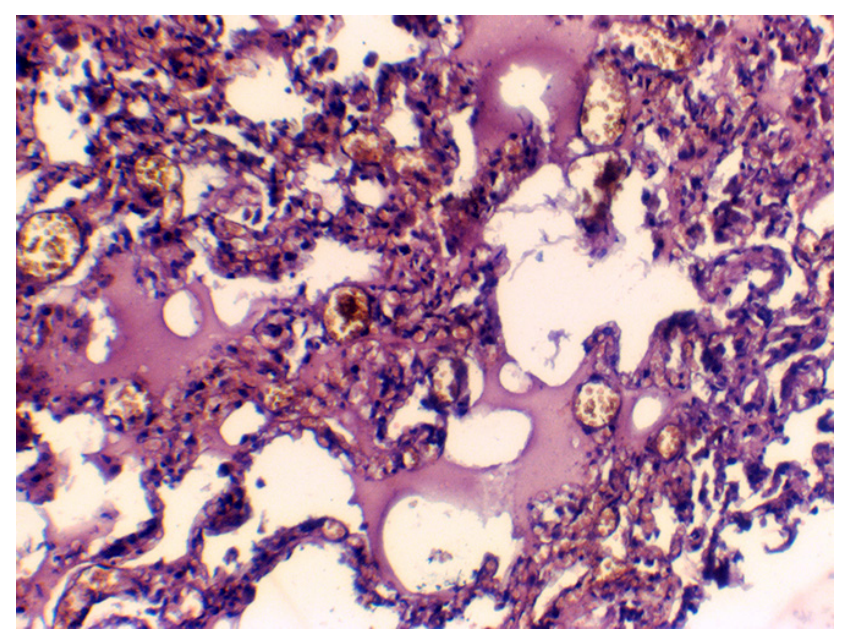

Рис. 2. Повнокров'я мікроциркуляторного русла, сладж-феномен. Дистелектаз альвеол. Інтерстиціальний та альвеолярний набряк. Гістологічний зріз некропсії легень. Забарвлення гематоксиліном і еозином. ×160. 
витку гострої ниркової дисфункції. Розлади кровообігу характеризувалися нерівномірним кровонаповненням шарів із переважанням повнокров’я пірамід (рис. 3). Периваскулярні ділянки розширені та пухкі, містять незначну кількість волокнистої сполучної тканини. Клубочки переважно звичних розмірів, проте в усіх спостерігалося знижене кровонаповнення. В просвітах окремих капсул Шумлянського - Боумена містилася серозна рідина (рис. 3).

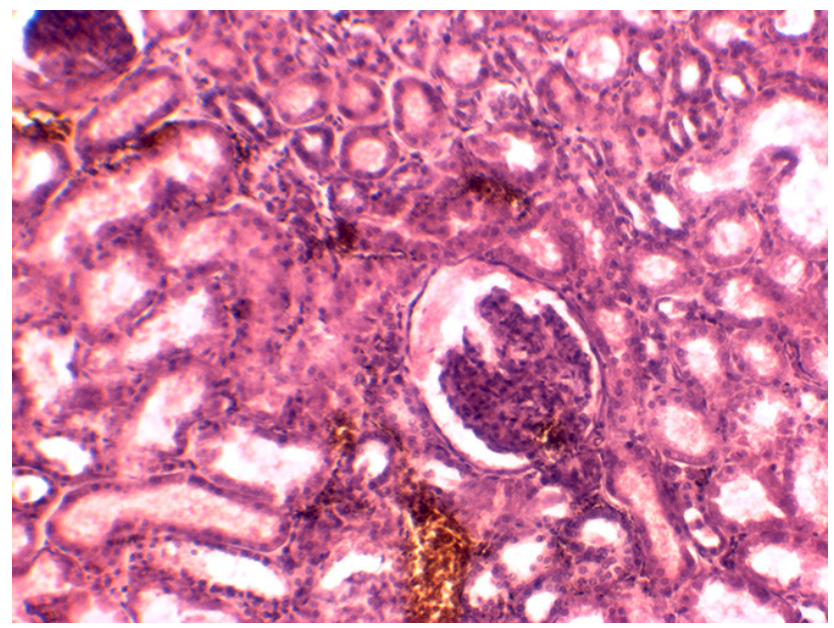

Рис. 3. Колапс судинного тільця із наявністю серозної рідини в просвіті капсули Шумлянського-Боумена. Дистрофічні зміни епітелію канальців. Повнокров'я судин. Гістологічний зріз некропсії нирки. Забарвлення гематоксиліном і еозином. ×200.

Проміжна тканина кіркового шару виражена слабо із нерівномірним інтерстиціальним набряком. Епітелій дистальних та проксимальних відділів канальців був збережений, щільно прилягав до базальної мембрани. Однак в частині випадків дистрофічні зміни були різко виражені, що проявлялося вакуолізацією цитоплазми нефроцитів, апікальною чи повною десквамацією у поєднанні із осередковим тубулонекрозом. Просвіти більшості з них були звужені або повністю закриті за рахунок набубнявіння нефроцитів. В розширених просвітах виявлялися аморфні білкові маси.

Судинне русло печінки також характеризувалося венозним і капілярним повнокров'ям з агрегацією еритроцитів біля судинних стінок. На багатьох ділянках характерна балково-радіальна структура часточок збережена. Цитоплазма гепатоцитів гомогенна відносно світла 3 центрально розміщеним ядром. Інші клітини мали тьмяну цитоплазму з нечіткими контурами ядер. На тлі нерівномірно вираженого капілярно-венозного повнокров'я з еритростазами спостерігалося нерівномірне розширення (набряк) перисинусоїдальних просторів Діссе, що варіювало від слабкого до вираженого (рис. 4).

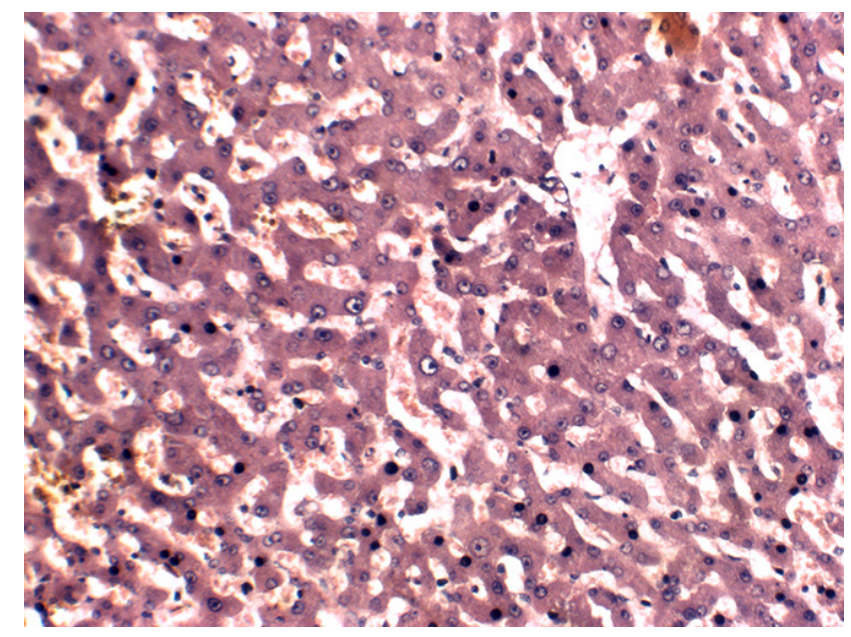

Рис. 4. Різко виражений набряк перисинусоїдних просторів. Дистрофічні зміни гепатоцитів. Гістологічний зріз некропсії печінки. Забарвлення гематоксиліном і еозином. $\times 100$.

У зрізах надниркових залоз переважало слабке кровонаповнення кіркового шару та його часткова дискомплексація. Маніфестувала субтотальна виражена деліпідизація цитоплазми адренокортикоцитів клубочкової і пучкової зон кори. В окремих випадках виявлялися крововиливи в мозковому шарі (рис. 5).

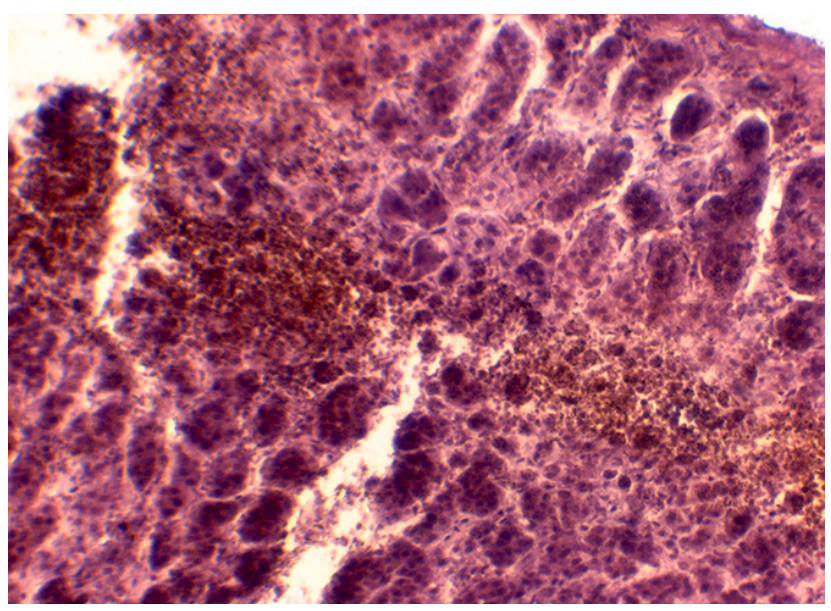

Рис. 5. Деліпідизація цитоплазми адренокортикоцитів клубочкової і пучкової зон кори. Крововиливи в мозковому шарі. Гістологічний зріз некропсії надниркової залози. Забарвлення гематоксиліном і еозином. $\times 200$.

Проведений аналіз світлооптичної структури серця, нирок, легені, печінки, надниркових залоз свідчить, що при ГП розвивається комплекс однотипних неспецифічних морфологічних змін внутрішніх органів, що проявляються порушенням мікроциркуляції, підвищенної судинної проникності, дистрофічними і некротичними змінами, які доцільно вважати морфологічною основою поліорганної дисфункції. 
Висновки. 1. Комплекс супутніх захворювань у хворих на ГП: міокардіодистрофії, респіраторного дисстрес-синдрому дорослих, гострої ниркової, печінкової та наднирковозалозної недостатності зумовлює безпосередню причину смерті зазначених пацієнтів, що пояснюється єдністю патогенетичних ланок ураження органів і систем i трактується як поліорганна недостатність.

Розлади гемодинаміки $є$ найбільш типовою причиною розвитку поліорганної недостатності, мали генералізований характер і проявлялися

\section{СПИСОК ЛІТЕРАТУРИ}

1. Хірургічне лікування захворювань підшлункової залози / Б. Г. Безродний, В. М. Короткий, І. В. Колосович, Р. А. Сидоренко. - Київ : Видавництво, 2011. - 252 с.

2. Заднипряный И. В. Изменения сократительных кардиомиоцитов и гемомикроциркуляторного русла у беременных и новорожденных крыс в условиях гемической гипоксии / И. В. Заднипряный, О. С. Третьякова, Т. П. Сатаева // Российский медико-биологический весник имени академика И. П. Павлова. - 2015. - Т. 23, № 2. - С. 19-25.

3. Емельянов С. И. Хирургический эндотоксикоз как проблема клинической гастроэнтерологии / С. И. Емельянов, Б. С. Брискин, Д. А. Демидов [и др.] // Эксперим. и клин. гастроэнтерол. - 2010. - № 7. - С. 67-73.

4. Покотило В. Ю. Морфологічні особливості міокарда та його мікроциркуляторного русла на світлооптичному рівні за умов перебігу експериментальної опіоїдної інтоксикації / В. Ю. Покотило, У. М. Галюк, Л. Р. Матешук-Вацеба // Вісник проблем біології і медицини. - 2017. - Вип. 4, Т. 2 (140). - С. 123-128.

5. Свиридюк В. 3. Алгоритм діагностики хронічного панкреатиту в поліморбідних пацієнтів / В. 3. Свиридюк // Су- набряком, стазом крові з утворенням мікротромбів у мікроциркуляторному руслі, що призводило до гіпоксичного пошкодження функціональних клітин і стромальних компонентів внутрішніх органів.

Перспективи подальших досліджень. Морфологічні прояви поліорганної недостатності доцільно доповнити методом дисперсного аналізу із клінічними проявами різних клініко-морфологічних типів гострого панкреатиту. часна гастроентерологія. - № 5 (37). - 2007. - С. 42-53.

6. Стяжкина С. Н. Острый деструктивный, панкреатит: диагностика и лечение / С. Н. Стяжкина, В. А. Ситников, А. В. Леднева // Международный журнал прикладных и фундаментальных исследований. - 2011. - № 5. - С. 110-112. 7. Профілактика гнійно-септичних ускладнень гострого некротичного панкреатиту у хворих похилого та старечого віку / І. М. Шевчук, Р. Т. Кузенко, М. Г. Шевчук [та ін.] // Науковий вісник Ужгородського університету. Серія “Медицина”. - 2011. - Вип. 2(41). - С. 294-297.

8. Fluid resuscitation in acute pancreatitis / T. B. Gardner, S. S. Vege, R. K. Pearson [et al.] // Clin. Gastroenterol. and Hepatology. - 2008. - Vol. 6. - P. 1070-1076.

9. Management of the critically ill patient with severe acute pancreatitis / A. B. Nathens, J. R. Curtis, R. J. Beale [et al.] // Crit. Care Med. - 2004. - Vol. 32. - P. 2524-2536.

10. JPN Guidelines for the management of acute pancreatitis: medical management of acute pancreatitis / K. Takeda, T. Takada, Y. Kawarada [et al.] // J. Hepatobiliary Pancreat. Surg. - 2006. Vol. 13. - P. 42-47.

\section{REFERENCES}

1. Bezrodnyi, B.H., Korotkyi, V.M., \& Kolosovych, I.V., \& Sydorenko, R.A. (2010). Khirurhichne likuvannia zakhvoriuvan pidshlunkovoi zalozy [Surgical treatment of pancreatic diseases]. Kyiv [in Ukrainian].

2. Zadnipryanyy, I.V., Tretyakova, O.S., \& Satayeva T.P. (2015). Izmeneniya sokratitelnikh kardiomiotsytov i gemomikrotsyrkulyatornogo rusla u beremennikh i novorozhdennykh kris v usloviyakh khemicheskoy gipoksii [Changes in contractile cardiomyocytes and hemocirculatory circulation in pregnant and newborn rats under conditions of hemic hypoxia]. Rossiyskiy mediko-biologicheskiy vestnik imeni akademika I.P. Pavlova Russian Medical and Biological Journal named after academician I.P. Pavlov, 23, 2, 19-25 [in Russian].

3. Emelyanov, S.I., Bryskin, B.S., \& Demidov, D.A. (2010). Khirurgicheskiy endotoksikoz kak problema klinicheskoy gastroenterologii [Surgical endotoxicosis as a problem of clinical gastroenterology]. Eksperimentalnaya i klin. gastroenterologiya - Experimental and Clinical Gastroenterology, 7, 67-73 [in Russian].

4. Pokotylo, V.Yu., Haliuk, U.M., \& Mateshuk-Vatseba, L.R. (2017). Morfolohichni osoblyvosti miokarda ta yoho mikrotsyrkuliatornoho rusla na svitlooptychnomu rivni za umov perebihu eksperymentalnoi opioidnoi intoksykatsii [Morphological

features of the myocardium and its microcirculatory bed at the light-optical level under the conditions of the experimental opioid intoxication]. Visnyk problem biolohii i medytsyny - Bulletin of Biology and Medicine, 4, 2 (140) 123-128 [in Ukrainian].

5. Svyrydiuk, V.Z. (2007). Alhorytm diahnostyky khronichnoho pankreatytu $\mathrm{v}$ polimorbidnykh patsiientiv [Algorithm for diagnosis of chronic pancreatitis in multimorbid patients]. Suchasna hastroenterolohiia - Modern Gastroenterology, 5 (37), 42-53 [in Ukrainian].

6. Styazhkina, S.N., Sytnikov, V.A., \& Ledneva, A.V. (2011). Ostryy destruktivnyy, pankreatit: diagnostika i lecheniye [Acute destructive, pancreatitis: diagnosis and treatment]. Mezhdunarodnyy zhurnal prykladnikh i fundamentalnikh issledovaniy - International Journal of Applied and Fundamental Research, 5, 110 -112 [in Russian].

7. Shevchuk, I.M., Kuzenko, R.T., \& Shevchuk, M.H. (2011). Profilaktyka hniino-septychnykh uskladnen hostroho nekrotychnoho pankreatytu u khvorykh pokhyloho ta starechoho viku [Prevention of purulent-septic complications of acute necrotic pancreatitis in elderly and senile patients]. Naukovyi visnyk Uzhhorodskoho universytetu, seriia "Medytsyna" Scientific Herald of Uzhhorod University, series "Medicine", 2 (41), 294-297 [in Ukrainian]. 
8. Gardner, T.B., Vege, S.S., \& Pearson, R.K. (2008). Fluid resuscitation in acute pancreatitis. Clin. Gastroenterol. and Hepatology, 6, 1070-1076.

9. Nathens, A.B., Curtis, J.R., \& Beale, R.J. (2004) Management of the critically ill patient with severe acute pancreatitis. Crit.
Care Med., 32, 2524-2536.

10. Takeda, K., Takada, T., \& Kawarada, Y. (2006). JPN Guidelines for the management of acute pancreatitis: medical management of acute pancreatitis. J. Hepatobiliary Pancreat. Surg., 13, 42-47.

YA. YA. BODNAR ${ }^{1}$, I. YA. DZIUBANOVSKYI ${ }^{1}$, T. K. GOLOVATA ${ }^{1}$, P. YA. BODNAR ${ }^{1}$, N. O. SUSLOVA ${ }^{2}$, L. P. BODNAR

I. Horbachevsky Ternopil State Medical University ${ }^{1}$

Heart Institute of the Ministry of Health of Ukraine ${ }^{2}$

\title{
FEATURES OF STRUCTURAL CHANGES OF THE INTERNAL ORGANS IN PATIENTS WITH ACUTE PANCREATITIS IN CONDITIONS OF POLYMORBIDITY
}

\begin{abstract}
The aim of the work: to find out the regularities of the processes of internal organs remodeling of the dead from complicated pancreatitis in conditions of polymorbidity.

Materials and Methods. A retrospective analysis of 163 protocols of autopsy and pathohistological examination of necropsies of the dead from acute surgical pathology was conducted. Among them, acute pancreatitis as the underlying disease was diagnosed in 30 people, that was $18.5 \%$ of the total number of analyzed protocols.

Results and Discussion. According to autopsy data, concomitant cardiovascular pathology was diagnosed, namely aortic atherosclerosis (73.3 \%), IHD (60.0\%), arterial hypertension (60.1\%), chronic obstructive pulmonary disease $(63.3 \%)$ and endocrinopathy (23.3\%),) Overall, the polymorbidity index was 4.7. A complex of structural changes in the heart, kidneys, lungs, liver and adrenal glands are structural components of multiorgan failure in acute pancreatitis. Microscopic research has established that the constant component in the pathogenesis of polyogenetic insufficiency in acute pancreatitis is the presence of varying degrees of severity of circulatory disorders in all internal organs.
\end{abstract}

Key words: internal organs; acute pancreatitis; polymorbidity.

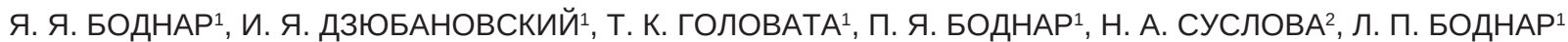

гВУз “Тернопольский государственный медицинский университет Мз Украины”

ГУ “Институт сердца МЗ Украины”.

\section{ХАРАКТЕРИСТИКА СТРУКТУРНЫХ ИЗМЕНЕНИЙ ВНУТРЕННИХ ОРГАНОВ ПРИ ОСТРОМ ПАНКРЕАТИТЕ ПРИ УС.ЛОВИИ ПОЛИМОРБИДНОСТИ}

\begin{abstract}
Цель работы: выяснить закономерности процессов ремоделирования внутренних органов умерших от осложненного панкреатита в условиях полиморбидности.

Материалы и методы. Проведен ретроспективный анализ 163 протоколов вскрытий и патогистологического исследования некропсий умерших от острой хирургической патологии. Среди них острый панкреатит как основное заболевание диагностировано у 30 человек, что составляет 18,5 \% от всего количества проанализированных протоколов.

Результаты исследований и их обсуждение. По данным вскрытия диагностировано сопутствующую сердечно-сосудистую патологию, а именно атеросклероз аорты (73,3 \%), ИБС (60,0 \%), артериальную гипертензию (60,1\%), а также ХОБЛ (63,3 \%) и эндокринопатии ( 23,3 \%). В целом индекс полиморбидности составлял 4,7. Структурной составляющей полиорганной недостаточности при остром панкреатите является комплекс структурных изменений сердца, почек, легких, печени и надпочечников. Микроскопическим исследованием установлено, что постоянной составляющей в патогенезе полиорганной недостаточности при остром панкреатите является наличие разной степени выраженности расстройств кровообращения во всех внутренних органах.
\end{abstract}

Ключевые слова: внутренние органы; острый панкреатит; полиморбиднисть. 